\title{
The Role of Community in Disaster Mitigation: The Case of Umbulharjo Merapi Monitoring Community on Merapi Mount, Indonesia
}

\section{Adhianty Nurjanah}

Communication Studies, Universitas Muhammdiyah Yogyakarta, Indonesia adhianty@umy.ac.id

\section{Riski Apriliani}

Communication Studies, Universitas Gadjah Mada, Indonesia

riskiapriliani@mail.ugm.ac.id

Submitted: 2 August 2021; Revised: 2 September 2021; Accepted: 27 September 2021

\section{Check for updates}

\begin{abstract}
Abstrak
Bencana alam merupakan peristiwa yang banyak terjadi di Asia Tenggara, termasuk di Indonesia. Sebagai negara yang termasuk kedalam kawasan ring of fire dan mengalami banyak peristiwa bencana alam yang beragam, Indonesia memiliki pengalamannya sendiri dalam upaya penanggulangan resiko bencana, salah satunya yakni dengan keterlibatan dan peran aktif masyarakat. Oleh karena itu, penelitian ini akan menganalisa peran penting Umbulharjo Merapi Monitoring Community (UMMC)—sebuah komunitas masyarakat yang fokus mengawasi Gunung Merapi di Daerah Istimewa Yogyakarta-berkomitmen sebagai penyedia informasi untuk memantau langsung kondisi Merapi dan berperan menginisiasi program yang fokus dalam mitigasi bencana. Hasil dari penelitian ini bertujuan untuk menunjukkan bahwa peran penting masyarakat mutlak diperlukan dalam program mitigasi sehingga dapat menadi referensi model penanggulangan bencana pada daerah rawan bencana diwilayah Asia Tenggara. Penelitian ini menggunakan metode deskriptif kualitatif dan data diperoleh melalui proses wawancara mendalam dengan melibatkan warga masyarakat, akademisi dan pemerintah Kabupaten Sleman. Hasil penelitian mengungkapkan bahwa mitigasi bencana yang dilakukan oleh UMMC terdiri dari empat tahap yaitu identifikasi, analisis, treating, monitoring dan evaluasi. Dari tahapan-tahapan tersebut disusunlah beberapa program untuk pengurangan resiko bencana diantaranya counseling, training, collaborate with stakeholders, and mentoring. Kata Kunci: Peran Masyarakat, Mitigasi Bencana, UMMC, Indonesia.
\end{abstract}

\begin{abstract}
Natural disasters are events that often occur in Southeast Asia, including in Indonesia. As it is situated in the ring of fire area and has faced different kinds of natural disaster events, Indonesia has their own experiences in disaster risk management, one of which is the involvement and active role of the community. Therefore, this study will analyze the important role of Umbulharjo Merapi Monitoring Community (UMMC) - a community that focuses on monitoring Mount Merapi in the Special Region of Yogyakarta—-that is committed as the provider of information regarding Merapi condition through a direct monitor and plays the role in initiating programs that focus on disaster mitigation. The results of this study aims to show that the role of the community is necessarily required in the mitigation program so that it can be a reference for disaster management models in disaster-prone areas in the Southeast Asian region. This study used a qualitative descriptive method and the data were obtained through an in-depth interview process involving community members, academicians and the government of Sleman Regency. The results of the study revealed that the disaster mitigation carried out by UMMC consisted of four stages that are: identification, analysis, treating, monitoring and evaluation. Through these four stages, several programs for disaster risk reduction are arranged, such as counselling, training, collaborating with stakeholders, and mentoring.
\end{abstract}

Keywords: Role of Community, Disaster Mitigation, UMMC, Indonesia.

\section{INTRODUCTION}

Natural disaster is a global problem of which the places of the globe. Natural disasters contributes a huge mitigation effort of ones can be adopted in the other negative impact to the humankind such as fatalities, 
property losses, environtmental and facility damage, to the international investments problems. According to the United Nations agency for the International Strategy for Disaster Risk Reduction, Indonesia is one of the countries that is prone to various natural disasters such as earthquakes, tsunamis, volcanic eruptions, floods, landslides, droughts, and forest fires. In 2015-2019, Indonesia was categorized as a country with the potential for natural disasters abd ranked $35^{\text {th }}$ globally. Eruptions and earthquakes due to theactive volcanic activity become the most frequent disaster to be found in Indonesia. This kind of disaster keeps people cautious and feel unsafe as it may happen anytime unexpectedlly. One of the active volcanic eruptions that needs to be cautious of is the potency of Mount Merapi eruption in Sleman Regency in Yogyakarta Special Region. It is recorded that the eruption of Mount Merapi in 2010 resulted 275 fatalities (Detik News, 2010), and in 2018, there were 12 more phreatic eruptions. Lastly, in early 2021 , the eruption of Mount Merapi experienced 26 times of hot douds that required people to be evacuated in a state of Covid-19 pandemic (Bramasta, 2021). The disaster mitigation of Mount Merapi eruption needs to be handled and managed seriously, as it also becomes a concerning issues to international communicy. Reffering to the news of Kompas International, there are international media who also glanced at the news of the eruption of Mount Merapi and reported it to the whole world. Among them, The Guardian (Europe), Reuters (France), The Strais Time (Singapore), Deutsche Welle (Germany) (Iswara, 2020). Therefore, the handling of disaster mitigation of the eruption of Mount Merapi id very important because it effects the security interests of the local community and the image of Indonesia which is ready for disaster mitigation in the tourism area especially on Mount Merapi.

Hence, disaster mitigation is not only a problem borne by the government but also a shared obligation and responsibility to Pentahelix collaborate between the government, academia, media, corporate, and also the most important is community (Windiani, 2020). The community has an important role to provide inspiration and spirit for the community. The community themselves must be supported by the government, in order to be able to be organized before and after disaster (Pyles, 2007). Effort is carried out to contribute to disaster mitigation, aiming to prevent and respond to disasters both before, during, and after a disaster occurs. The community has a significant role in emphasizing the need for awareness of living in disaster-prone areas (Harini, 2010). Moreover, the most highlighted thing is the role of the community around Mount Merapi, who are aware that they are in disaster-prone areas and have groups in empowering the community. One of the disaster awareness groups in the disaster-prone area of Kepuharjo, Umbulharjo, Sleman is the Umbulharjo Merapi Monitoring Community (UMMC). The existence of UMMC is also recognized by the regulation of the Yogyakarta Special Region Government Number 8 of 2010 Article 7 related to Disaster Management and community participation (Yogyakarta Patent No. 8, 2010). UMMC has an important role in the management of the Mount Merapi eruption disaster because it has a program that invites the community around Umbulharjo to know what to do in dealing with Merapi. UMMC's major roles include counseling, training, creating an IoT-based disaster communication system, and monitoring.

Furthermore, based on our research, up to this date, most of the previous researches put their focus on the central role of government rather than the community, such as the effort of technology development dan the legal basis (Wei, Jin, \& Wang, 2012). Meanwhile another research focuses on the centrality of technology for mitigating disaster (Suganuma, 2006). There is a research that focuses on the role of the community in natural disasters in Cambodia, but it just explains how the role of the community in collaborating with stakeholders (Nareth, 2017). This research looks at how the community can also play central role to mitigate disaster, before, during, and after disaster. Indonesia does in dealing with disasters is strengthened by the support of society. So this research will fill the gap in the role of disaster mitigation in the international realm in the aspect of community contribution in disaster mitigation. This is because disaster is a big problem and it is necessary to adopt changes in adapting to disaster. Indonesia does 
in dealing with disasters is strengthened by the support of society. so this research will fill the gap in the role of disaster mitigation in the international realm in the aspect of community contribution in disaster mitigation. This is because disaster is a serious problem and it is necessary to adopt changes in adapting to disaster.

This research is in accordance with the above argument that disaster mitigation requires a central role for the community, so this study tries to explain how the Merapi community plays a significant role in disaster mitigation. To discuss our argument on the central role of UMMC in disaster mitigation, the discussion will be devided in to three section. The first section will discuss about Merapi eruption and the present of UMMC, the second section will discuss about profil of UMMC, and the last section discuss about the implementation model of UMMC disaster mitigation program. This research has novel value that will contribute to the field of science in handling the Mount Merapi eruption disaster so this research can be useful as a reference in Indonesia and as a reference in disaster management in Southeast Asia.

\section{LITERATURE REVIEW}

There are five groups involved in the disaster management; government, academicians, media, companies, and the most importantly is communities. In this context, we use a community-based disaster mitigation approach to show that the community is capable of mitigating disasters and is very instrumental in reducing the risk of the Mount Merapi eruption disaster. Our literature review includes Disaster Mitigation Approach, the Role of Community Disaster, and Disaster Awareness from the community.

\section{DISASTER MITIGATION APPROACH}

Disaster mitigation is a series of efforts to reduce disaster risk through physical development and awareness as well as capacity building to face the physical disaster threats and the non-physical one (Djalante, Garschagen, Thomalla, \& Shaw, 2017). Disaster mitigation must be carried out for all disaster situations, both natural disasters and man-made disasters. Mitigation is intended to reduce losses both material and immaterial in the form of casualties that will affect life and subsequent human activities. Disaster mitigation is a science that studies disasters and all aspects related to disasters, especially disaster risk and how to avoid disaster risk. Disaster mitigation is a dynamic process of how the management functions that we know so far work, such as the planning, organizing, actuating, and controlling functions (Nurjanah, 2013).

Potential losses caused by disasters can be reduced through mitigation. Mitigation is defined to reduce and prevent the risk of loss of life and property through structural and non-structural approaches (Nursa'ban, Sugiharyanto, \& Khotimah, 2010). Structural mitigation is an effort to reduce disaster risk through physical development and technical engineering of disaster-resistant buildings, while non-structural mitigation aims to reduce non-physical disaster risks such as policies, community empowerment, institutional strengthening, and awareness (Sugiharyanto, Wulandari, \& Wibowo, 2014). In reducing disaster risk, non-structural mitigation is more sustainable because it provides security in the long term (Dewi et al., 2016). Some aspects of supporting disaster mitigation include the role of the disaster community in responding to disasters, including the role of the community in strengthening community participation in disasters, and disaster awareness by the community.

\section{THE ROLE OF COMMUNITY BASED DISASTER RISK MANAGEMENT CONCEPT}

The importance of such concepts as one of the approach to manage and reduce disaster risk we know in 2001 the government, civil societies and communities across Southeast Asia participated in the Partnerships for Disaster Reduction-South East Asia that promotes Community Based Disaster Risk Management (CBDRM) (Nareth, 2017). CBDRM is becoming healthier for Southeast Asia because this region consist of countries that are prone to disasters. The Asian Disaster Preparedness Center (ACPC) defines the role of communities in disaster mitigation as those who are active in identifying, analyzing, treating, monitoring, and evaluation of disaster risk in order to reduce their vulnerabilities and enhance their capacities (Abarquaze 
\& Murshed, 2004). (1) Identification is the possibility that the community can identify what needs to be conveyed and what preparations are needed before a disaster occurs. (2) Analyzing is to see how the community is able to analyze from identification activities to filter some data in the field and adjust the conditions needed before conveying it to the community. (3) Treating, showing that the community is able to provide the best service in pre, during, and post-disaster events and assists in the process of understanding how to deal with disasters. (4) Monitoring, which is to see whether the suitability of the information conveyed to the community in disaster-prone areas is in accordance with the initial concept or not. (5) and lastly, evaluation is an activity to evaluate and measure how the activities are carried out with the natural disasters encountered (Abarquaze \& Murshed, 2004).

Another opinion was conveyed by Lavell, who said that local communities always have a wider perspective than people outside the community (Lavell, 2008). At the same time, through local participation, the community understood the importance of such programs/activities and can communicate well between them and the higher authority. This is supported by Abarquez and Murshed (2004), who points out that citizen participation promotes commitment to decisions, and the decision taken deals directly. However, it is worth to take note that disaster mitigation even the smallest scale can be delicate matters thus it needs a strong collaboration from different stakeholders in order to make it successful. This study will highlight the role of community to mitigate disaster and strengthening local public to aware of natural disaster especially the eruption of Mount Merapi disaster.

\section{THE COMPONENTS OF THE EFFECTIVENESS COMMUNITY ROLE IN DISASTER MITIGATION}

The importance of civil society for community development, explaining that the safety of a community should be a matter of discussion and determination by the community because ultimately, communities and individuals must be responsible for their safety (Nakagawa $\&$ Shaw, 2004). Moreover, the disaster preparedness community is a condition of the community having an awareness of natural disaster events, knowing the types of disasters in the area they live in, and having adequate knowledge about potential disasters (Putra, 2014).

When the community plays a role in providing awareness to the community, there are several things that support the level of effectiveness of the community's role in disaster mitigation. Several studies of theory and previous research, it can be concluded that the role of the community in disaster mitigation consists of 5 components that make the implementation of disaster mitigation by the community run effectively. Nareth (2017) argues that 5 points that support the effectiveness of the community's role in disaster mitigation include local knowledge, decision making, local resources, stakeholder involvement, local participation.

1. Local Knowledge, Knowledge for local communities is very important to help the each other prepare or provide response and recovery as quickly and effectively as possible (Mark, Spranger, \& Kumaran, 2014). In this study, the local capacity in question is how the community's knowledge of disaster mitigation has been taught by the UMMC group. Knowledge in the community will support the community to face disaster preparedly, and with the provision of knowledge it will create the next generation of what must be prepared in dealing with disasters.

2. Decision Making, Decision making in the community will help make effective decisions and adapt to the needs and desires of the community. Decisions in this study mean decisions regarding resource mobilization, resource allocation, intervention and strategic planning in disaster mitigation. Because effective decision making will support success in dealing with disasters (Abarquaze $\&$ Murshed, 2004).

3. Local Resource, Resources in this local resource refer to financial, local labor contributions in the form of goods that are formed and made by local communities. Without resources activities will not be effective enough. The availability of these local resources must be integrated with the priorities 
resources must be integrated with the priorities needed by the surrounding community.

4. Stakeholder Involvement, greatly supports the success of the community's role in disaster mitigation. The reason is that disaster management is a complex situation that requires resources from outside and from the local community. With these stakeholders, it will encourage local communities and the government to move and have the same interests. Successful programs will encourage stakeholder participation as one of their top priorities. This allows stakeholders to collaborate with local communities and local governments (Quzai, 2010).

5. Local Participation, Communities in disaster-prone areas are involved in planning and implementing disaster risk management activities and in collaboration with entities at the local, provincial and national levels. This risk management is community based to reduce vulnerability and strengthen community capacity in dealing with hazards and disasters. The community must be directly involved in the implementation for disasters at the local level.

Based on the five components above, this research will focus on discussing how to apply local knowledge, local resources, stakeholder involvement and local participation in community-based disaster mitigation. Because in the context of the UMMC Program, the dominant component is more directed to community involvement in awareness in dealing with disasters, not related to decision choices or decision making.

\section{RESEARCH METHOD}

This study belongs to qualitative descriptive research as researchers act as the key instrument in describing phenomena, and research results are emphasized more meaningfully than generalizations on scientific objects. Bodgan Taylor in Moelong defined a qualitative approach as a research procedure that produces descriptive data in written or spoken words from individuals researched and observed (Moleong, 2017). In this study, the data were collected from two sources: primary sources were obtained from in-depth interview with community groups in Pangukrejo Umbulharjo Village (UMMC members) in Sleman and the Regency Disaster mitigation Agency (BPBD) of Sleman. Secondary data were obtained through literature studies and document studies related to community empowerment in disaster mitigation, especially the Mount Merapi eruption in Yogyakarta. The data analysis was carried out using the Miles and Huberman (1992) model, by means of triangulation of sources, so as to obtain appropriate and accurate data. Data analysis is a process of compiling and simplifying data to make it easier to read and interpret.

This method was selected based on the need to explore information and discover more about the importance of community role model carried out by the UMMC in performing disaster mitigation. To reduce bias in the data, the researchers conducted a in-depth interview with the UMMC community, attended by 5 men and 4 women. Their background is the Pangukrejo community with jobs such as farmers, civil servants, and housewives. We have tried to make questions that can be answered by all informants, but in the in-depth interview process the male group was active in conveying their aspirations and only one woman dared to speak up other than those conveyed by the men. It is possible that the participation of men's groups is more involved in disaster mitigation than women's.

\section{RESULT AND ANALYSIS}

Based on the literature review, this section will discuss the phenomenon of the role of the community in the UMMC community in dealing with the eruption of Mount Merapi. This discussion consist of three sections, the first section discusses the phenomenon of Mount Merapi eruption and the involvement of the UMMC. In the second section, it discusses what efforts have been made by UMMC in disaster mitigation, and the last is to assess the effectiveness of the implementation and involvement of UMMC in disaster management of the eruption of Mount Merapi. 


\section{MERAPI ERUPTION AND THE PRESENT OF UMMC}

Mount Merapi is the most active volcano in Indonesia with a very high potential of disaster. According to modern records, this mountain always erupts every two to five years. It becomes increasingly dangerous for human life because the slopes of this mountain are already surrounded by dense settlements. Magelang City and Yogyakarta City are the closest major cities, less than 30 $\mathrm{km}$ from the summit, making them highly disaster-prone areas. The eruption of Merapi in 1872 is considered the strongest eruption in the records of the modern era of geology and in October - November 2010 the eruption of Merapi was the highest eruption since 1872 which killed 277 people. It was recorded that 2,636 houses were severely damaged and unfit for habitation, 156 houses were moderately damaged, and 632 houses were slightly damaged, so that a total of 3,424 houses in the Yogyakarta region were damaged as a result of the eruption of Mount Merapi. Entering 2021, volcanic activity is increasing. After more frequent observations of lava rock debris from previous eruptions and thicker white smoke/steam from the summit, on January 4 , 2021, silent hotspots and avalanches of volcanic material (rock and lava) began to be observed.

Since 2010, the model for dealing with the eruption of Mount Merapi has changed from being top to bottom, namely from the government to the community, but the trend after 2010 is that people must participate in observing the situation in disaster-prone areas. Therefore, the community has a high involvement in forming a community related to the eruption of Mount Merapi. One of the communities that plays a very important role is the UMMC, which is at the forefront of helping other communities and has the courage to sacrifice their body and soul to help other victims. They are a disaster preparedness community and are ready to inform the current state of Mount Merapi's. Information regarding the location and the number of victims and data collection on their needs is required to facilitate officers and volunteers in helping disaster victims. Moreover, the UMMC is active in opening up and often getting cooperation in disaster management.
The presence of UMMC is the result of regulations supported by the government that the need for community and community involvement in disaster risk reduction is in accordance with 2017 the regulation of the Yogyakarta Special Region Government Number 8 of 2010 Article 7. UMMC does not have a complete structure other than the chairman and secretary of the community.

"We only have the chairman and secretary of the community. This is to support the decision and we choose Pak Dukuh of Pangukrejo to be the head of the UMMC community. Besides that, we don't need structural recognition because the most important thing in disaster mitigation is to move and be responsible for helping each other in dealing with disasters," (Riyanto, UMMC community secretary, in-depth interview result April 2, 2021).

The spirit of the formation of UMMC is the awareness of young people to protect each other and to make people aware that they are in disaster-prone areas. So the UMMC community carried out several programs as an effort to reduce the risk of dangerous disasters. UMMC consists of youth groups in Pangukrejo, consisting of men. The number of community administrators consists of 20 people, so they are aware of the need for further programs to make the community stronger and ready to face disasters. The UMMC community is also a Merapi management community that often collaborates with several researchers and receives service grants because of their preparedness in dealing with the disaster.

\section{THE ROLE OF UMMC IN DISASTER RISK COMMUNITY}

Umbulharjo Merapi Community Monitoring is one form of building resilience to disasters and is in the form of a Community Based Disaster Risk Reduction (CBDRR) project. CBDRR is based on the understanding that the community has local wisdom and knowledge. Therefore, they are the right parties in identifying the threats and risks faced and the efforts needed to anticipate them. The need for information on disaster-prone locations, the number of previous victims, 
and data collection on the needs of victims are needed to facilitate officers and volunteers in helping disaster victims. Referring to the role of the disaster mitigation community according to the Asian Disaster Preparedness Center (2003) what UMMC does by seeking information, this is a form of disaster mitigation activities in the first stage, namely identifying the appropriate. Identification according to the UMMC community is very helpful in directing what needs to be done and adjusting the program to be made.

"The form of identification of the situation that we do is one of them monitoring the condition of Mount Merapi directly and if in a state of danger we convey information through the tradition of disaster communication media and social media," (Subagyo, UMMC community leader, in-depth interview result April 2, 2021).

Based on the results of the identification, the UMMC community then analyzed the situation and considered whether an immediate evacuation was necessary or simply urging the community to prepare valuables. In the conditions for evacuating, UMMC realized the limited capacity in dealing with Merapi during a disaster, so the UMMC community began educating the community.

"On several occasions that required evacuation, we finally learned and realized that we also need cooperation with the whole community. So we made a program to educate the community" (Subagyo, UMMC community leader, in-depth interview result April 2, 2021).

The implementation of community strengthening carried out by UMMC aims to educate the public in dealing with the natural disaster of the eruption of Mount Merapi. This arose from UMMC's awareness that they live in disaster-prone areas.

"We realize that the community will always want a sense of security and leaders who begin to provide guidance, from this spirit because I also as a hamlet took the initiative with other residents to create this community whose goal is to provide protection and a sense of security. security for our own citizens, as well as for the community, helping foreign tourists who usually travel in the Mount Merapi area," (Subagyo, Dukuh Pangukreho and chairman of UMMC, in-depth interview result April 2, 2021).
Community in the contect of UMMC understood as people who shared common identification to each other and shared same experience and threat to common hazards, common experience in responding to and experience in the reconstruction period, although the might have difference perceptions of exposure to risk. This will ensure the communities to have a sense of belonging to such plan that should help each other. Through the role of the community, it can ensure that the community is safe and has a strong role to protect other people (Nareth, 2017).

Furthermore, after treating the community, the UMMC community conducted a review by monitoring the Pangukrejo community. Monitoring is carried out to find out what is still needed by the community and whether there are things that are still not understood in understanding the handling of disaster mitigation. So if we analyze the role of the UMMC community with the Asian Disaster Preparedness Center approach model, then UMMC has carried out 5 components that can be carried out, namely identification, analysis, treating, and monitoring and evaluation. The form of evaluation carried out by the UMMC community was when they realized that the community could not only work alone but needed the community. So the results of the evaluation became the forerunner of the UMMC disaster mitigation model program. The model for the community-based disaster mitigation program designed by UMMC is as follows

\section{DISASTER MITIGATION MODEL OF UMMC PROGRAM}

The above section has discussed the present of UMMC and the role of this organisation in disaster mitigation. This section will discuss more specific on four activities (namely counseling, training, collaborate with stakeholders and monitoring) that UMMC applies in their programme and arguable this has become an ideal model of disaster mitigation within Indonesian community nowadays. This section will discuss more details each activities and explain why it has successful to mitigate disaster. 
1. Counseling

Counselling aims to maintaining the community, improve welfare independently, and build civil society. Counseling is to produce beneficial behavior and action changes. Through this program, it is hoped that the lower class community groups can be raised to become middle and upper-class community groups. The counseling stages applied to this model have succeeded in providing direction and understanding of the community to make changes and have an open mind in finding information related to disasters.

"The first time we did counseling aimed to make people aware. Counseling is here as the first stage of effort to convey information and call for awareness that the public is alert because they are in disaster-prone areas".

(Subagyo, Dukuh Pangukreho and chairman of UMMC, in-depth interview result April 2, 2021).

This is also supported by a statement from the community, Mrs. Sodiyah who said that the presence of UMMC helps the community feel safe because every day there are always reports from the community regarding the situation of Mount Merapi.

"Every day we get the status of Merapi from the hamlet,

$R T$ and RW who are conveyed through the mosque's toa. At the same time urging residents to remain vigilant and prepare to evacuate when the siren sounds, at least this is what makes us not always in a state of anxiety," (Sodiyah, Pangukrejo Umbulharjo community, in-depth interview, 2 April 2021)."

Through communication related to the eruption of Mount Merapi, it will provide increased public awareness regarding the threat of the eruption of Mount Merapi. Public awareness is required to support mitigation activities. In addition to the existence of a solid legal framework to be used as a guideline in carrying out mitigation activities and the availability of forums or institutions responsible for disaster mitigation activities, public awareness of disaster mitigation efforts is also necessary, one of which is mitigation.

At this counseling stage, it is in accordance with the concept of local knowledge from measuring the effectiveness of the community's role in carrying out effectiveness of the community's role in carrying out disaster mitigation according to Nareth (2017). Knowledge in the community will support the community to face disaster preparedly, and with the provision of knowledge it will create the next generation of what must be prepared in dealing with disasters.

2. Training

Training was applied, where the presenters and mentors from the training were responsible for providing explanations and directions assisted by the local government implementer (Irmawati, 2018). UMMC in providing training to the surrounding community by adopting the material obtained when community leaders are selected by The Regional Disaster Management Agency to attend disaster mitigation training. It was conducted not to violate and adjust the results of previous research that disaster mitigation agencies have carried out.

The Regional Disaster Management Agency (RDMA) that every community has the right to protection and a sense of security, including in situations of disaster.

"The community has the right to social protection and a sense of security, especially for groups of people who are vulnerable to disasters. BPBD as the government has an obligation to strive for the fulfillment of the rights of the community related to disaster management. This is done through training so that the community has the ability and insight, especially how to protect themselves and their families, especially during disasters." (Asih Kurniasih, secretary of RDMA of Sleman, in-depth interview result April 20, 2021).

After receiving knowledge from the training delivered by BPBD, UMMC conveyed it again by conducting further training to the surrounding community.

"This is a program to make people not only aware of being in a disaster-prone area but also to be able to prepare themselves and know what to do in the event of a disaster. (Subagyo, Dukuh Pangukreho and chairman of UMMC, in-depth interview result April 2, 2021). 
The ability to convey back the training provided by BPBD Sleman, is a local resource that supports disaster mitigation. The UMMC community with the willingness of supporting human resources will fully support the need for community independence in strengthening each other in pre, during, and post-disaster situations.

\section{Collaborate with Stakeholders}

The role of community disaster mitigation model carried out by the UMMC collaborated with any stakeholders, including academia and also regional disaster management agencies. The form of collaboration with academics is to design a disaster communication system. The design of this system began with the initiation of a Communication Science Lecturer at Universitas Muhammadiyah Yogyakarta (UMY) in implementing disaster communication. In this design, there was a need for communication tools to inform the public with an IoT system, with the flow of obtaining data for early detection of natural disasters from disaster agencies, then designing tools to broadcast information to the local community on the potential and warnings of the Mount Merapi eruption. In implementing this community communication, the media also utilized handphones (HP) and handy talkies (HT) to inform simultaneously, considering that $\mathrm{HT}$ was an effective communication tool in disaster mitigation.

"The purpose of this collaboration is to create an early warning system related to community-based disaster communication to be able to help the community. The concept of this communication system is to make a siren, which initially requires one person to convey the siren early warning system through the mosque. However, we modified this concept with signals from the BPTKG system going into the internet and directly entering mosques so that mosques can inform directly without the need for the public to sound a warning through the TOA Mosque ", (Iswanto, lecturer in informatics engineering UMY, in-depth interview result April 21, 2021).

Stakeholder involvement greatly supports the success of the community's role in disaster mitigation. The reason is that disaster management is is a complex situation that requires resources from outside and from the local community. With these stakeholders, it will encourage local communities and the government to move and have the same interests. Successful programs will encourage stakeholder participation as one of their top priorities. This allows stakeholders to collaborate with local communities and local governments (Quzai, 2010).

\section{Mentoring}

Mentoring is the last stage as a form of assistance from the stages of delivering information, conducting training, and collaborating with several stakeholders. Mentoring is intended so that people who receive disaster mitigation training from UMMC can maintain their understanding and hope that when a disaster occurs, it will reduce disaster risk. In this mentoring, UMMC also collaborates with related agencies, such as the local government, BPBD of Sleman, and UMY, to conduct training following SOPs and design an IoT-based system. This effort was carried out to have an equal and balanced standard of training and strengthening the community in dealing with the natural disaster of the Mount Merapi eruption.

At the mentoring stage which involves collaboration with the local government and local academics, it will support the spirit of the local community to work together to help each other and always be prepared because they live in disaster-prone areas. Through this mentoring, it will prepare the involvement of local communities in participating in tackling the Mount Merapi eruption disaster.

"We hope that this monitoring can strengthen the quality of each training and program that we deliver to the local community. From there we can maximize community participation to support disaster mitigation. So the concept is gotong royong". (Subagyo, Dukuh Pangukreho and chairman of UMMC, in-depth interview result April 2, 2021).

Communities in disaster-prone areas are involved in planning and implementing disaster risk management activities and in collaboration with 
entities at the local, provincial and national levels. This risk management is community based to reduce vulnerability and strengthen community capacity in dealing with hazards and disasters. The community must be directly involved in the implementation for disasters at the local level (Nareth, 2017).

Programs owned by UMMC can be an example of a form of community that can be adopted by other international countries in disaster mitigation. Things that have been done by this community include providing support for disaster mitigation training independently and in collaboration with stakeholders who care about disasters, providing innovation in community-based disaster communication patterns, and UMMC is able to provide solutions and alternatives in disaster mitigation.

Based on the above discussion, the following table shows the summary of the disaster care community UMMC model to overcome the Mount Merapi disaster:

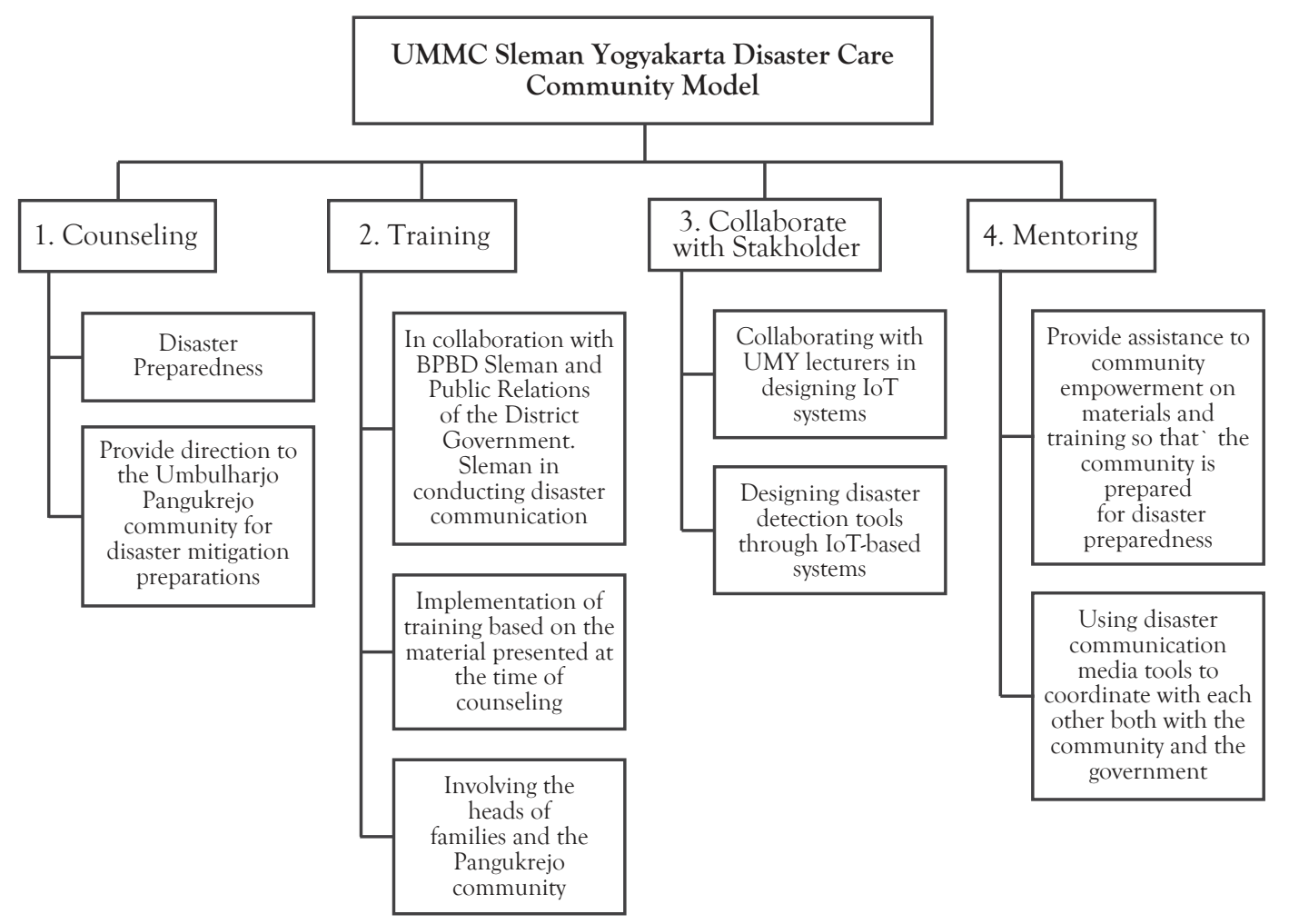

Figure 1. UMMC Sleman Yogyakarta Disaster Care Community Model (Data collected and compiled from interviews)

Moving on to disaster-prone areas in the Southeast Asia realm such as Cambodia and the Philippines, they also have their own approach to empowering communities and using communities in handling disaster communications. However, the initiation of the existence of a community is based on regulations from the government (Redcross, 2020; Nareth, 2017). However this research shows that communities have their own characteristics that make them unique and it is important to become familiar with these things as they impact on the community recovery process and they can also play central role in disaster mitigation. What has been done by the UMMC community has aspects in common with what is considered important by countries that have a high potential for natural disasters. However, UMMC has more value in terms of initiating collaboration related to an IoT-based disaster communication system approach. This is not encountered by communities in Southeast Asia in disaster mitigation. 
Reflecting on this, this study recommends the role of the community to design an environmental system that functions as an early disaster risk handler. The community in charge of disaster mitigation needs to adopt several things that UMMC does, including identifying disaster conditions, analyzing disaster conditions according to the needs of the surrounding community, conducting training to support awareness and knowledge of other communities related to natural disasters, conducting mentoring and monitoring to assist the community with maintained understanding, and evaluating.

It needs to be highlighted that the concept of the approach in dealing with disasters needs to be adapted to the type of disaster and the habits of the community. So that the chosen approach adapts to Indonesia's socio-cultural system, as stated by BNPB, namely Indonesia's innovative policies prioritize the role of local communities, are environment-based and utilize science and technology and disaster research. Thus, the role of UMMC in disaster mitigation is a tangible form of strengthening disaster risk communities to educate, provide assistance, and provide an appropriate communication system that can be used in disaster risk areas of the Mount Merapi eruption and can be a recommendation for disaster risk areas in the international realm to deal with disasters.

\section{CONCLUSION}

Based on the above discussion, it shows that the community's involvement is very crucial in the disaster mitigation efforts. One of the communities that play a role in mitigating the eruption of Mount Merapi is UMMC. UMMC functions as an information provider to monitor the current condition of Merapi directly, and the results are presented to the public. UMMC plays a role in reducing disaster risk through increasing public understanding of disaster mitigation. The form of disaster mitigation initiation from UMMC is through the stages of identification, analysis, treating, monitoring and evaluation. From these stages several programs for disaster risk reduction have been prepared including counseling, training, collaborating with stakeholders, and mentoring. What has been done by UMMC has implemented the concept of community role in disaster mitigation according to the Asian Disaster Preparedness Center and has a level of effectiveness in program implementation because it has implemented the values of local knowledge, local resources, stakeholder involvement, and local participation. And the results of the program implementation carried out by UMMC received a good response from the local community. Referring to the results obtained, this research can be a reference in handling disaster mitigation by several countries in Southeast Asia that have high natural disaster potential such as Combodia and the Philippines. Even though Cambodia and the Philippines have implemented a community role approach, the full initiation of the community and community participation is a more important point than the government which must mobilize the entire community to care for disasters.

\section{REFERENCE}

Abarquaze, I., \& Murshed, Z. (2004). Community-Based Disaster Risk Management: Field Practitioners Handbook. Thailand: Asian Disaster Preparedness Centre.

Bramasta, D. B. (2021, January 27). Erupsi Gunung Merapi, Luncurkan 36 Kali Awan Panas dalam 14 Jam Halaman all Kompas.com. Retrieved July 24, 2021, from Kompas.com website: https://www.kompas.com/tren/read/2021/01/27/17 2343865/erupsi-gunung-merapi-luncurkan-36-kali-awan -panas-dalam-14-jam? page = all

Detik News. (2010, November 18). BNPB: Jumlah Korban Tewas Merapi 275 Orang. Retrieved July 24, 2021, from Detik News website: https://news.detik.com/berita/d-1496723/ bnpb-jumlah-korban-tewas-merapi-275-orang

Dewi, I. K., Istiadi, Y., \& Istiadi, Y. (2016). Mitigasi Bencana Pada Masyarakat Tradisional Dalam Menghadapi Perubahan Iklim di Kampung Naga Kecamatan Salawu Kabupaten Tasikmalaya. Jurnal Manusia Dan Lingkungan, 23(1), 129. https://doi.org/10.22146/jml. 18782

Djalante, R., Garschagen, M., Thomalla, F., \& Shaw, R. (2017). Disaster Risk Reduction in Indonesia: Progress, Challenges, and Issues. New York: Springer International Publishing

Harini, S. (2010). Membangun Masyarakat Sadar Bencana. Jurnal Dakwah, 11(2), 157-171.

Iswara, A. J. (2020, 3 3). Internasional.compas.com. Retrieved Agustus 2021, from Kompas.com: https://internasional. kompas.com/read/2020/03/03/18530881/erupsi-gunung -merapi-jadi-perhatian-media-internasional?page=all

Lavell, A. (2008). Relationships between Local and Community Disaster Risk Management \& Poverty Reduction: A Preliminary Exploration. United Nations: ISDR Global Assessment Report on Disaster Risk Reduction. 
Mark, B. R., Spranger, M., \& Kumaran, M. (2014). ffective Community Response to Disaster: A Community Approach to Disaster Preparedness and Response. In Mark Brennan, R. C., Michael Spranger, and Muthusami Kumaran. (2014). Effective Community Response to Disaster: A Community Approach to Disaster Preparedness and Response. (pp. 1-5). FLorida: Institute of Food and Agricultural Sciences.

Miles, B. M., \& Huberman, M. (1992). Analisis Data Kualitatif Buku Sumber Tentang Metode-metode Baru. Jakarta: UI Press.

Moleong, L. J. (2017). Metodelogi Penelitian Kualitatif Edisi Revisi. Bandung: Remaja Rosdakarya.

Nareth, M. C. (2017). Disaster Management in Cambodia: Community Based Disaster Risk Management In The Case of Drough in Aoral District. Thammasat University, Asia Pasific Studies. Thailand: Thammasat University. Retrieved from http://tiara-tu.ac.th/uploadFiles/145939_a30dd13530479 c216e08ddef428e2660.pdf

Nakagawa, Y., \& Shaw, R. (2004). Social Capital: A Missing Link to Disaster Recovery. International Journal of Mass Emergencies and Disaster, 22(1), 1-5.

Nurjanah, A. (2013). Pemberdayaan Masyarakat Urban (Miskin Perkotaan) PT Sari Husada Yogyakarta Melalui Program Corporate Social Responsibility (CSR) Rumah Srikandi. Repository UMY, 1-17. Retrieved from http://repository.umy .ac.id/bitstream/handle/123456789/1392/PNLT2234.pdf? .seq

Nurjanah, A., Ishak, A., \& Sakir. (2019). E-Government of Sleman Regency Government Public Relations in Disaster Communication of Merapi Eruption. Proceeding of International Conference Singapore, 28-31. Singapore: IRAJ. Retrieved from https://www.worldresearchlibrary.org/ up_proc/pdf/3312-157424260828-31.pdf

Nursa'ban, Sugiharyanto, \& Khotimah. (2010). Pengukuran Kerentanan Longsor Lahan Sebagai Upaya Mitigasi Bencana Di Perbukitan Menoreh. Jurnal Penelitian Saintek, 15(2), 45-52.

Pyles, L. (2007). Community Organizing for Post-Disaster Social Development. International Social Work, 50(3), 321-333.

Putra, G. S. (2014). Pemberdayaan Masyarakat dalam Mitigasi Bencana Alam di Kabupaten Klaten. Universitas Diponegoro.

Quzai, U. (2010). Implementing people-centred reconstruction in urban and rural areas building back better. London: International Federation.

Redcross. (2020). Philippines: Disaster preparedness on a local level. Retrieved September 25, 2021 from Redcross Germany website: https://www.drk.de/en/aid-worldwide/ where-we-work/grc-in-asia/philippines-improving-local -planning-for-disaster-preparedness-and-prevention/

Suganuma, K. (2006). Recent Trends in Earthquake Disaster mitigation in Japan. Quarterly Review, 19(1), 91-106.

Sugiharyanto, Wulandari, T., \& Wibowo, S. (2014). Persepsi Mahasiswa Pendidikan IPS Terhadap Mitigasi Bencana Gempa Bumi. JIPSINDO, 2(1), 164-182.

The Regulation of Special Region of Yogyakarta. (2010). Yogyakarta Patent No. 8.

Wei, Y. M., Jin, J. L., \& Wang, Q. (2012). Impacts of Natural Disasters and Disasters Risk Management in China: The Case of China's Experience in Wenchuan Earthquake. Economic and Welfare Impacts of Disasters in East Asia and Policy
Responses, 641-67

Windiani. (2020). Pentahelix Collaboration Approach in Disaster Management: Case Study on Disaster Risk Reduction Forum-East Java. The 2nd International Conference on Global Development - ICODEV. 7, pp. 71-77. IPTEK Journal of Proceedings. 